\title{
SUMMER 2019
}

\section{The}

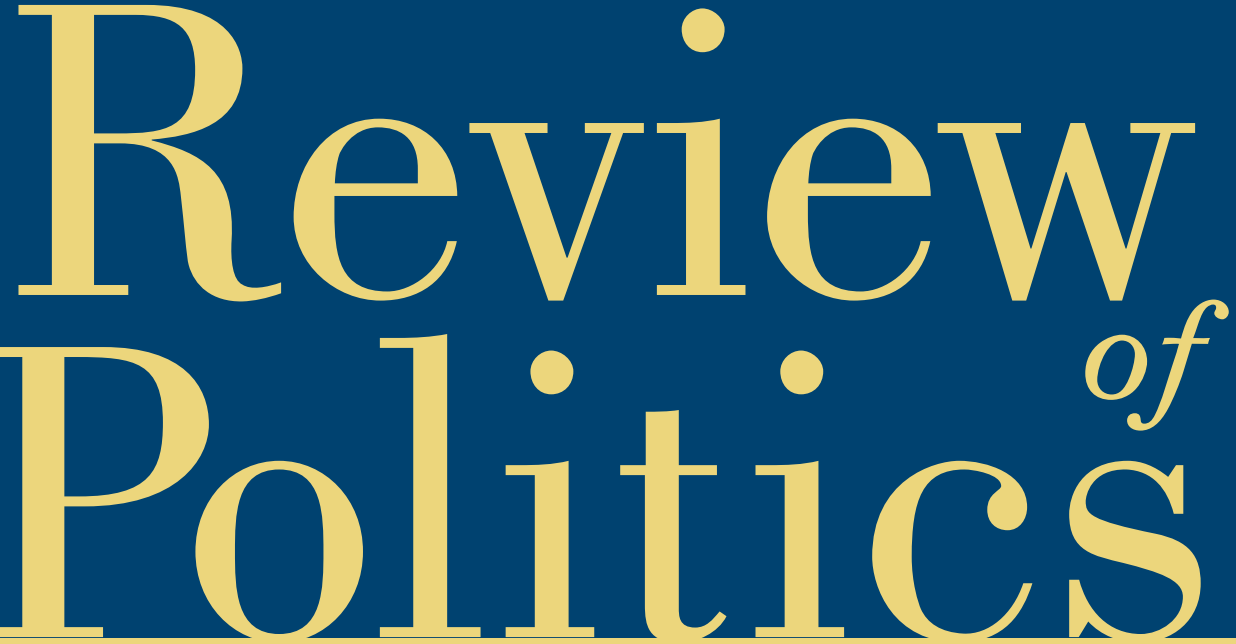

ARTICLES

Catherine R. Power, "Figural Judaism and Political Thought in the Marquis d'Argens's Lettres juives"

Boris Litvin, "Staging Emile: Audience and Genre in Collective Self-Legislation"

Paul Sagar, "Liberty, Nondomination, Markets"

Aaron Maltais, Jonas Hultin Rosenberg, and Ludvig Beckman,

"The Demos and Its Critics"

Zhuoyao Li, "Political Confucianism and Multivariate Democracy

in East Asia" with a reply by Sungmoon Kim and response by Li

Review Essay: Catherine H. Zuckert, "Machiavelli: Radical Democratic Political Theorist?" 


\title{
THE REVIEW OF POLITICS
}

\author{
Editor \\ RUTH ABBEY \\ Book Review Editor \\ SUSAN D. COLLINS \\ Interim Book Review Editor \\ MARY M. KEYS \\ Editorial Coordinator \\ KELLI BROWN
}
Editorial Board
Shlomo Avineri
Hebrew University of Jerusalem
Simone Chambers
University of California, Irvine
Barry Cooper
University of Calgary
Fred Dallmayr
University of Notre Dame
John Dunn
Cambridge University
Elizabeth Frazer
University of Oxford
Michael A. Gillespie
Duke University
Leslie Goldstein
University of Delaware
Russell Hittinger
University of Tulsa
Ramin Jahanbegloo
York University
Xiaofeng Liu
Renmin University of China
Pierre Manent
L'Ecole des Hautes Etudes en
sciences sociales
Harvey C. Mansfield
Harvard University
Daniel Philpott
University of Notre Dame
Arlene Saxonhouse
University of Michigan
William E. Scheuerman
Indiana University, Bloomington
John T. Scott
University of California, Davis
Steven B. Smith
Yale University
Peter Steinberger
Reed College
Vickie Sullivan
Tufts University
Jean M. Yarbrough
Bowdoin College

\section{Copyeditor: LES HARRIS}
Editorial Interns: Alejandro Castrillon and Tyler Thomas

\section{Former Editors}

Waldemar Gurian

M.A. Fitzsimons

Donald P. Kommers

Thomas Stritch

Walter Nicgorski

Frederick J. Crosson

The Review of Politics publishes primarily philosophical and historical studies of politics, especially those in political theory and American political thought. The journal also includes thoughtful scholarly reflections on all aspects of politics-laws, and institutions, international relations, comparative politics - as well as literary reflections on politics or political interpretations of literature. 


\section{TABLE OF CONTENTS SUMMER 2019}

Vol. 81

Summer 2019

No. 3

Catherine R. Power

Figural Judaism and Political Thought in the

Marquis d'Argens's Lettres juives . . . . . . . . . . . . . . . 363

Boris Litvin

Staging Emile: Audience and Genre in Collective

Self-Legislation . . . . . . . . . . . . . . . . . . . 381

Paul Sagar

Liberty, Nondomination, Markets . . . . . . . . . . . . . . . 409

Aaron Maltais, Jonas Hultin Rosenberg, and Ludvig Beckman

The Demos and Its Critics ... . . . . . . . . . . . . . 435

Zhuoyao Li

Political Confucianism and Multivariate Democracy in

East Asia . . . . . . . . . . . . . . . . . . . . . . . . 459

Sungmoon Kim

Reasonable Pluralism and Pragmatic Confucian Democracy:

Reply to Zhuoyao Li . . . . . . . . . . . . . . . . . . 485

Zhuoyao Li

Between Confucianism and Democracy: A Response to

Sungmoon Kim . . . . . . . . . . . . . . . . . . . 493

Review Essay:

Catherine H. Zuckert

Machiavelli: Radical Democratic Political Theorist?

Reviews:

Karie Cross Riddle

Review of Alexandre Lefebvre's Human Rights and the Care of the Self and Brooke Ackerly's Just Responsibility: A Human Rights Theory of Global Justice.

Richard E. Blanton

Review of James C. Scott's Against the Grain: A Deep History of the Earliest States.

Joan Cocks

Review of Demetra Kasimis's The Perpetual Immigrant and the Limits of Athenian Democracy. 


\section{Nick Cowen}

Review of William A. Edmundson's John Rawls:

Reticent Socialist.

Jonathan F. Culp

Review of Jacob Howland's Glaucon's Fate: History, Myth, and

Character in Plato's "Republic" . . . . . . . . . . . . . . . . . . . . . . . . . . . . 524

Ryan P. Hanley

Review of Paul Sagar's The Opinion of Mankind: Sociability and the Theory of the State from Hobbes to Smith. . . . . . . . . . . . . . . . . .527

David LaRocca

Review of Susan McWilliams Barndt's The American Road Trip and American Political Thought.

Marc A. LePain

Review of Paul Stern's Dante's Philosophical Life: Politics and Human Wisdom in "Purgatorio" .

Benjamin T. Lynerd

Review of Gregg L. Frazer's God against the Revolution: The Loyalist Clergy's Case against the American Revolution . .

Benjamin Storey

Review of Douglas I. Thompson's Montaigne and the Tolerance of Politics . . . . . . . . . . . . . . . . . . . . . . . . . . . . . .537

Robert S. Taylor

Review of Christopher Freiman's Unequivocal Justice

Neil Walker

Review of Angelica Maria Bernal's Beyond Origins: Rethinking

Foundations in a Time of Constitutional Democracy

Bradley C. S. Watson

Review of Matthew W. Slaboch's A Road to Nowhere: The Idea of Progress and Its Critics. 
Subscription Information: The Review of Politics (ISSN 0034-6705) is published quarterly in February, May, August and November by Cambridge University Press, One Liberty Plaza, 20th Floor, New York, NY 10006, USA/University Printing House, Shaftesbury Road, Cambridge CB2 8BS, UK for the University of Notre Dame. Annual subscription rates for Volume 81 (2019): Institutional subscription rates, print and online: US $\$ 218.00$ in the USA, Canada, and Mexico; UK $£ 128.00$ + VAT elsewhere. Institutional subscription rates, online only: US $\$ 180.00$ in the USA, Canada, and Mexico; UK $£ 110.00$ + VAT elsewhere. Institutional subscription rates, print only: US \$207.00 in the USA, Canada, and Mexico; UK $£ 125.00$ + VAT elsewhere. Individual subscription rates, print only: US $\$ 51.00$ in the USA, Canada, and Mexico; UK $£ 29.00+$ VAT elsewhere. Single part rates: US $\$ 60.00$ in the USA, Canada, and Mexico; UK $£ 36.00$ Correspondence concerning subscriptions should be sent to: Cambridge University Press, One Liberty Plaza, 20th Floor, New York, NY 10006, USA for customers in the USA, Canada, or Mexico. Customers elsewhere should contact: Cambridge University Press, University Printing House, Shaftesbury Road, Cambridge CB2 8BS, UK.

Editorial Office: All correspondence concerning submissions and manuscripts under review should be sent to The Review of Politics, University of Notre Dame, 2005 Jenkins Nanovic Halls, Notre Dame, IN 46556-7000. Phone: 574-631-6623. Email: ROP.Editor.1@nd.edu. Website: reviewofpolitics.nd.edu

Abstracting and Indexing Information: Articles in The Review of Politics are indexed in the International Index to Periodicals and the Catholic Periodicals and Literature Index; abstracted in the International Political Science Abstracts; and abstracted and indexed in ABC POL. SCI., Historical Abstracts, Social Science Index (also available in the electronic versions), Book Review Index, and International Bibliography of the Social Sciences.

Copyright (C) 2019 University of Notre Dame. All rights reserved. No part of this publication may be reproduced, in any form or by any means, electronic, photocopy, or otherwise, without permission in writing from Cambridge University Press, Rights and Permissions Manager, One Liberty Plaza, 20th Floor, New York, NY 10006, USA. For further information see http://us.cambridge/org/information/rights/

Periodicals postage paid in New York, NY and additional mailing offices. Postmaster: Send address changes to The Review of Politics, Cambridge University Press, One Liberty Plaza, 20th Floor, New York, NY 10006, USA.

Photocopying information for users in the U.S.A.: the Item-Fee Code for the publication (0034-6705/18 \$9.00 +.10) indicates that copying for internal or personal use beyond that permitted by Sec. 107 or 108 of the U.S. Copyright Law is authorized for users duly registered with the Copyright Clearance Center (CCC) provided that the appropriate remittance of $\$ 9.00$ per article is paid directly to CCC, 222 Rosewood Drive, Danvers, MA 01923. Specific written permission must be obtained for all other copying. 